\title{
Reviewer Acknowledgements for Global Journal of Health Science, Vol. 13, No. 6
}

Global Journal of Health Science wishes to acknowledge the following individuals for their assistance with peer review of manuscripts for this issue. Their help and contributions in maintaining the quality of the journal are greatly appreciated.

Global Journal of Health Science is recruiting reviewers for the journal. If you are interested in becoming a reviewer, we welcome you to join us. Please contact us for the application form at: gjhs@ccsenet.org.

\section{Reviewers for Volume 13, Number 6}

Abiodun Adeniran, University of Ilorin, Nigeria

Althea Jane Gamble Blakey, University of Otago, New Zealand

Angel Alfonso Velarde Lopez, University of Pennsylvania, Guatemala

António Calha, Polytechnic Institute of Portalegre, Portugal

Ayesha Johnson, University of South Florida, United States of America

Diamantis L. Floratos, National \& Kapodistrian University of Athens, Greece

Emad Adel Shdaifat, Imam Abdulrahman Bin Faisal University, Saudi Arabia

Faik Ardahan, Akdeniz University, Turkey

Farahnaz Amini, UCSI University, Malaysia

Gabriel Gulis, University of Southern Denmark, Denmark

Georgann Valerie Weissman, Capella University, United States

Helen Alcock-Towse, University of Lincoln, United Kingdom

Kartheek R Balapala, University Tunku Abdul Rahman, Malaysia

Meng Zhao, Texas A\&M University at Corpus Christi, United States of America

Pedram Iranmanesh, Dentist, Independent Researcher, Iran

Robert Sloan, Kagoshima University Graduate School of Medical and Dental Sciences, Japan

Roslyn Kane, University of Lincoln, United Kingdom

Thanusin Saleeon, Thaksin University, Thailand

Tulyakul Phatcharapon, Boromarajonani College of Nursing, Thailand 